\title{
Genetic profile for the detection of susceptibility to poisoning by exposure to pesticides
}

\author{
Hazael Ramiro Ceja Galvez, ${ }^{1, D, F} \oplus$, Joel Salazar Flores ${ }^{1, A, E-F} \oplus$, Erandis Dheni Torres Sanchez ${ }^{1, B-C \oplus}$, \\ Daniel Rojas Bravo ${ }^{2, C, E \oplus}$, Mireya Zoila Reyna Villela ${ }^{2, B} \oplus$, Emmanuel Reyes Uribe ${ }^{1, D-E \oplus}$ \\ ${ }^{1}$ Department of Medical and Life Sciences, University Center of the Cienega \\ ${ }^{2}$ Department of Technological Sciences, University Center of the Cienega \\ A - Research concept and design, B - Collection and/or assembly of data, C - Data analysis and interpretation, \\ $D$ - Writing the article, E - Critical revision of the article, $F$ - Final approval of article
}

Ceja Galvez HR, Salazar Flores J, Torres Sanchez ED, Rojas Bravo D, Reyna Villela MZ, Reyes Uribe E. Genetic profile for the detection of susceptibility to poisoning by exposure to pesticides. Ann Agric Environ Med. 2021; 28(2): 208-213. doi: 10.26444/aaem/136362

\begin{abstract}
Introduction. In humans, there are sets of genes that encode enzymes that decrease or increase the risks derived from exposure to pesticides. These include DNA repair genes (XRCC1, OGG1 and XRCC4); pesticide metabolizers (GSTP1 and PON1), and genes that act against oxidative stress (SOD2 and NQO1).

Objective. The aim of this literature review is to provide information about the genes involved in the defence systems against exposure to pesticides, as well as their polymorphisms, functions, and general characteristics of the encoded enzymes.

Materials and methods. Information was obtained from scientific articles published between 2015-2020 in the PubMed database (https://pubmed.ncbi.nlm.nih.gov).

Results. Genes related to the defence processes against pesticides present single-nucleotide polymorphisms (SNPs) with allelic variants that affect the expressions or structures of the encoded enzymes, negatively altering their activities. If we knew the genetic profile that includes polymorphisms of DNA-repairing genes, metabolizing genes, and genes against oxidative stress in subjects exposed to pesticides, we would also know about their susceptibility to poisoning caused by these chemicals.

Conclusion. The genes could be used to propose a genetic profile in farmers exposed to various pesticides, including 10 gene polymorphisms involved in susceptibility to various pathologies related to DNA repair, xenobiotic metabolism, and oxidative stress. It could also be useful as a preventive measure to identify susceptibility to pesticide poisoning.
\end{abstract}

Key words

pesticides, genetic profile, poisoning, metabolism, oxidative stress

\section{INTRODUCTION}

Pesticides are chemicals that are used to control any type of pest in agriculture, and used to increase crop production. Human exposure to pesticides is a recurring process due to pesticide residues in agricultural products and water. However, the most susceptible people to poisoning are farmers because they have direct contact with pesticides, and are unaware of the correct way to apply pesticides and therefore do not adopt safety measures [1-2]. Pesticideinduced disorders may be short-term or long-term, resulting mainly in poisoning and the formation of free radicals (highly reactive molecules with unpaired electrons). Poisoning is mainly due to the inhibition of enzymes, thereby interfering with signalling at cholinergic synapses in the central nervous system. Free radical formation triggers oxidative stress that leads to oxidative damage to biomolecules, DNA strand breaks, mutations in DNA, and ultimately cancer [3-5]. These incidents show that the misuse of pesticides and occupational exposure to them represent a serious public health problem, since there is an increase in pesticide-related diseases, for example; 1) the herbicide glyphosate is associated with the

Address for correspondence: Joel Salazar Flores, Universidad de Guadalajara, Av. Universidad, 47810, Ocotlán, Jalisco, Mexico

E-mail: joel.salazar@academicos.udg.mx

Received: 25.11.2020; accepted: 01.05.2021; first published: 24.05 .2021 development of kidney disease and decreased serum folic acid; 2) chemical lepidopterans with liver dysfunction, increased serum glucose, inflammation and severe damage to the nervous system; 3) organophosphate products with respiratory diseases, etc. [6, 7]. This public health landscape also leads to the discovery of new therapeutic opportunities, especially because treatments for diseases caused by organophosphate products have remained the same for approximately 50 years [7]. If we add that some genes involved in defence systems against pesticide poisoning can be affected by genetic factors, such as single nucleotide polymorphisms (SNPs), then a higher susceptibility would be expected in farmers who have variants with high risk of sensitivity [8-10].

\section{OBJECTIVE}

The objective of this literature review is to provide information about the genes that confer susceptibility to pesticide poisoning, as well as their polymorphisms, functions, and general characteristics of the encoded enzymes. The study is based on scientific studies written in English, published between 2015-2020, obtained from the PubMed database, using key words such as pesticides, XRCC1, OGG1, XRCC4, GSTP1, PON1, SOD2 and NQO1. The selected publications 
presented information related to the polymorphisms of each gene and their connection with the metabolism of pesticides. A total of 88 publications compatible with the review topics were analyzed, of which 57 were selected for the study.

\section{STATE OF KNOWLEDGE}

DNA repair genes. Pesticides can directly affect DNA of cells in exposed people, or they can do so indirectly through the production of ROS (Reactive Oxygen Species) that damage the genetic material due to mutagenic lesions or single or doublestranded DNA breaks [11-13]. The DNA repair pathways can be affected by different phenotypes of essential genes involved in these pathways. Base excision repair (BER) is one of the pathways involved in DNA single-strand break repair through the XRCC1 (X-Ray Repair Cross-Complementing Group 1) gene $[11,14]$. Other affected pathways are the repair of oxidative damage to guanine (8-oxoguanine) by the OGG1 (8-Oxoguanine DNA Glycosylase) gene [4, 10, 15]; and the non-homologous end-joint mechanism (NHEJ) that is responsible for the repair of double-stranded DNA breaks, by XRCC4 (X-Ray Repair Cross-Complementing Group 4) repair gene. The basic mechanism involved in each repair pathway is shown in Figure 1 [16-18].

XRCC1 is composed of 633 amino acids and has as molecular weightofs approximately $70 \mathrm{kDa}[12,19]$. XRCC1 is essential in the assembly of the BER pathway because it interacts and coordinates other major components such as polyADP-ribose polymerase-1 enzyme, DNA polymerase $\mathrm{H}$, and DNA ligase III, which are all involved in the repair of single-stranded DNA breaks induced by ROS (Fig. 1B)
[11-12, 20-22]. The XRCC1 gene is located on chromosome $19 \mathrm{q} 13.2$ with a length of $33 \mathrm{~kb}$, and comprises 17 exons and 16 introns $[12,14,19]$. Some polymorphisms in the XRCC1 gene have been used as biomarkers of susceptibility to DNA damage by pesticides. In this regard, the clinically relevant polymorphisms are $r s 1799782$ (exon 6 Arg194Trp $\mathrm{C} / \mathrm{T}$ ) and $r s 25487$ (exon 10 Arg399Gln G/A) [12-13,19-21]. The Arg194Trp polymorphism is located between two protein domains: the $\mathrm{NH} 2$-terminal domain and the BRCT1 domain that directly affects enzymatic function $[14,19]$. The Arg399Gln polymorphism is located at the C-terminus of the BRCT1 domain. It regulates the biological interaction with polyADP-ribose polymerase (PARP), resulting in reduced repair capacity, increased mutagenic sensitivity, and higher levels of DNA damage [12,19-21].

OGG1. The OGG1 gene is located on the long arm of chromosome 3 (3p26.2) and consists of 11 exons and 10 introns $[9,12,23]$. The enzyme encoded by this gene is 8 -oxoguanine DNA glycosylase, which acts directly on the BER pathway by catalyzing the repair of oxidative stress-induced damage to guanine $[4,15,24]$. The oxidation products of guanine are mostly 8-hydroxy deoxyguanosine (8-OHDG) and 8 -oxoguanine [24-26]. These oxidized guanine compounds are first detected by 8-oxoguanine DNA glycosylase that catalyzes the excision of the damaged base by cutting the glycosidic bond between the modified base and the sugar fraction, generating an abasic site (AP), which facilitates the subsequent addition of an unmodified base (Fig. 1A) [4, 2325]. The OGG1 gene has 163 polymorphisms, being the SNP rs1052133 (exon 7 Ser326Cys; G>C) of clinical relevance, since the allele mutated with the amino acid cysteine produces a

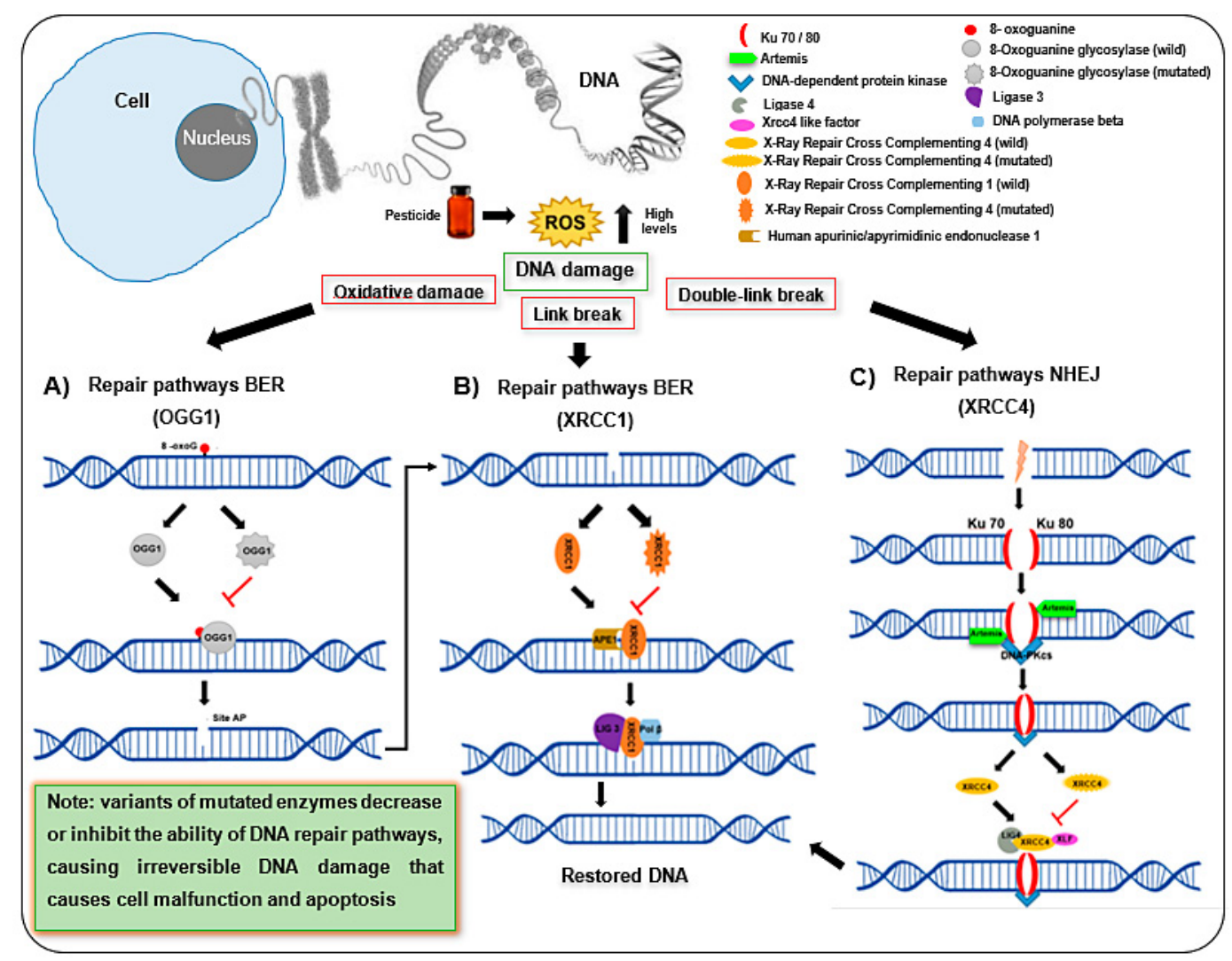

Figure 1. DNA repair genes. A: OGG1 as a DNA oxidation repairer, $\mathrm{B}: \mathrm{XRCC1}$ as a DNA helix break repairer, and C: XRCC4 as a DNA double helix break repairer 


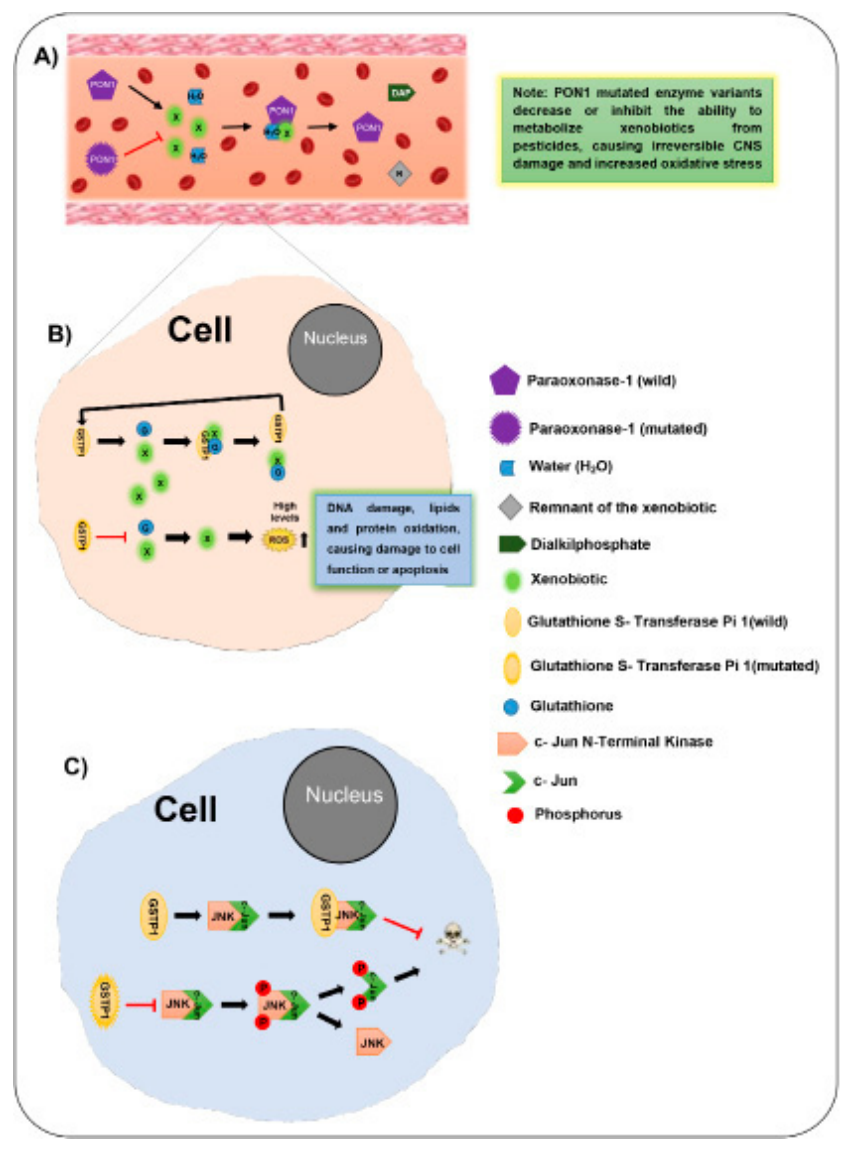

Figure 2. Xenobiotic metabolizing genes. A: PON1 hydrolyzes xenobiotics of organophosphate-type pesticides. B: GSTP1 is capable of metabolizing xenobiotics that increase oxidative stress. C: GSTP1 inhibits c-Jun activation through JNK by preventing apoptosis."

decrease in its capacity to repair oxidized bases, which leads to a greater susceptibility to genotoxicity and an increased risk of cancer $[9,12,15,26]$.

XRCC4. The XRCC4 gene is located on chromosome 5 at 5 14.2. It encodes a phosphoprotein called X-Ray Repair Cross-complementing Group 4 that contains 336 amino acids and three constituent domains $[17,27,28]$. This protein plays a major role in the NHEJ mechanism, which is necessary for the repair of double-stranded DNA breaks $[16,29,30]$. This process involves interaction with ligase 4 (Lig4) and factor XLF (XRCC4-factor, also known as Cernunnos or NHEJ1), thus facilitating ligation of the non-core and complementary ends of DNA $[16,28,30]$. These interactions involve critical domains in the XRCC4 protein: the N-terminal head domain is involved in DNA binding, and in the formation of the $X R C C 4 / X L F$ complex, while the coiled domain forms a complex with Lig4. Although the function of the C-terminus domain remains unknown, some studies indicate that it could facilitate the suppression of NHEJ in the M phase of the cell cycle [26]. The XRCC4-Lig4 complex forms a stable conjugate with the Ku70-Ku80 dimer [18, 28]. The XRCC4$X L F$ complex forms filaments at the breaks to join the broken ends and promote efficient ligation catalyzed by Lig4 (Fig. 1C) [28]. However, there is a polymorphism in the XRCC4 gene that influences its ability to repair DNA; this is the rs 28360135 polymorphism where an Ile134Thr change occurs due to T-C base change, so the mutated allele presents greater genotoxic damage $[18,29]$.
Genes involved in the metabolism of xenobiotics. Pesticides or some of their metabolites are xenobiotics that are toxic to humans; thus, some genes express enzymes which metabolize pesticides and their metabolites. The complex CYP450 plays an important role in phase 1 xenobiotic metabolism and consist of a broad family of monooxygenases, where each enzyme is highly polymorphic $[9,31]$. Glutathione transferases (GST) are a family of phase 2 metabolizing enzymes which catalyze the catabolism of electrophilic xenobiotics that produce free radical-induced oxidative stress, where the isoform $\pi$ (GSTP1) is the variant that metabolizes pesticides $[13,32$, 33]. PON1 is a phase 2 xenobiotic metabolizing enzyme that metabolizes organophosphate-type pesticides, thus avoiding cholinergic poisoning of farmers exposed to this type of pesticide [31, 34-35].

GSTP1. Pi-class glutathione-S-transferase (GSTP1) is a cytosolic homodimeric protein with two subunits, each with its active site ( $G S H$ binding site and an electrophilic substrate binding site, with molecular weights of 22 and 30 $\mathrm{kDa}$, respectively). This enzyme is encoded by the GSTP1 gene located on the long arm of chromosome 11 (11q13), with a length of approximately $2.84 \mathrm{~kb}[2,33]$. It acts in the detoxification of xenobiotics and as an antioxidant by inactivating harmful and carcinogenic electrophiles [32, $33,36]$. In addition, it can inhibit apoptosis by inactivating JNK1 (c-Jun N-terminal kinase-1), thus preventing $\mathrm{H}_{2} \mathrm{O}_{2}-$ induced apoptosis [2, 32]. However, there are genetic variants (SNP) that can directly affect the functionality of GSTP1, for example, the rs 1695 polymorphism has a downstream change in one base of exon 5 at position 313, from adenine to guanine, leading to a change from isoleucine to valine (ATC to GTC) at position 105 (Ile105Val). Therefore, individuals with the mutant variant have reduced enzyme activity that make them susceptible to oxidative stress and unable to detoxify cancer-causing xenobiotics (Fig. 2) [13, 37-39].

PON1. PON1 (Paraoxonase 1) is a phase 2 xenobiotic metabolizing enzyme that metabolizes organophosphatetype pesticides, thus avoiding cholinergic poisoning of farmers exposed to this type of pesticide [31, 34, 35]. It is a calcium-dependent glycoprotein with a molecular weight of $43 \mathrm{kDa}$ that contains approximately 354 amino acids. PON1 enzyme is encoded by the PON1 gene located on the long arm of chromosome 7 (7q21.22), with a length of $33.2 \mathrm{~kb}$ and 9 exons [34,40-41]. PON1 is synthesized in the liver where it forms a complex with high-density lipoproteins (HDL) before being transported to the bloodstream where it performs multiple functions through its activity on different target substrates [35,41-42]. One of its functions is the catabolism of organophosphate pesticides from which its name is derived (the first known substrate degraded by this enzyme was paraoxon due to its organophosphatase activity). PON1 also has arilesterase and lactonase activities and acts on oxidation residues in low-density lipoprotein (LDL) [35, 40, 41, 43]. However, its activity is affected by different polymorphisms present in its gene, and PON1 activity is affected by different polymorphisms present in its gene. In fact, around 400 polymorphisms have been identified, of which only three are of clinical relevance: one in the promoter region (rs705379; $-108 \mathrm{C} / \mathrm{T}$ ), and two in the coding region (rs854560, $\mathrm{A}>\mathrm{T}$, L55M; rs662, A $>$ G Q192R) [31, 34, 40, 44]. In the promoter region, there is a change at position 108 upstream, from 


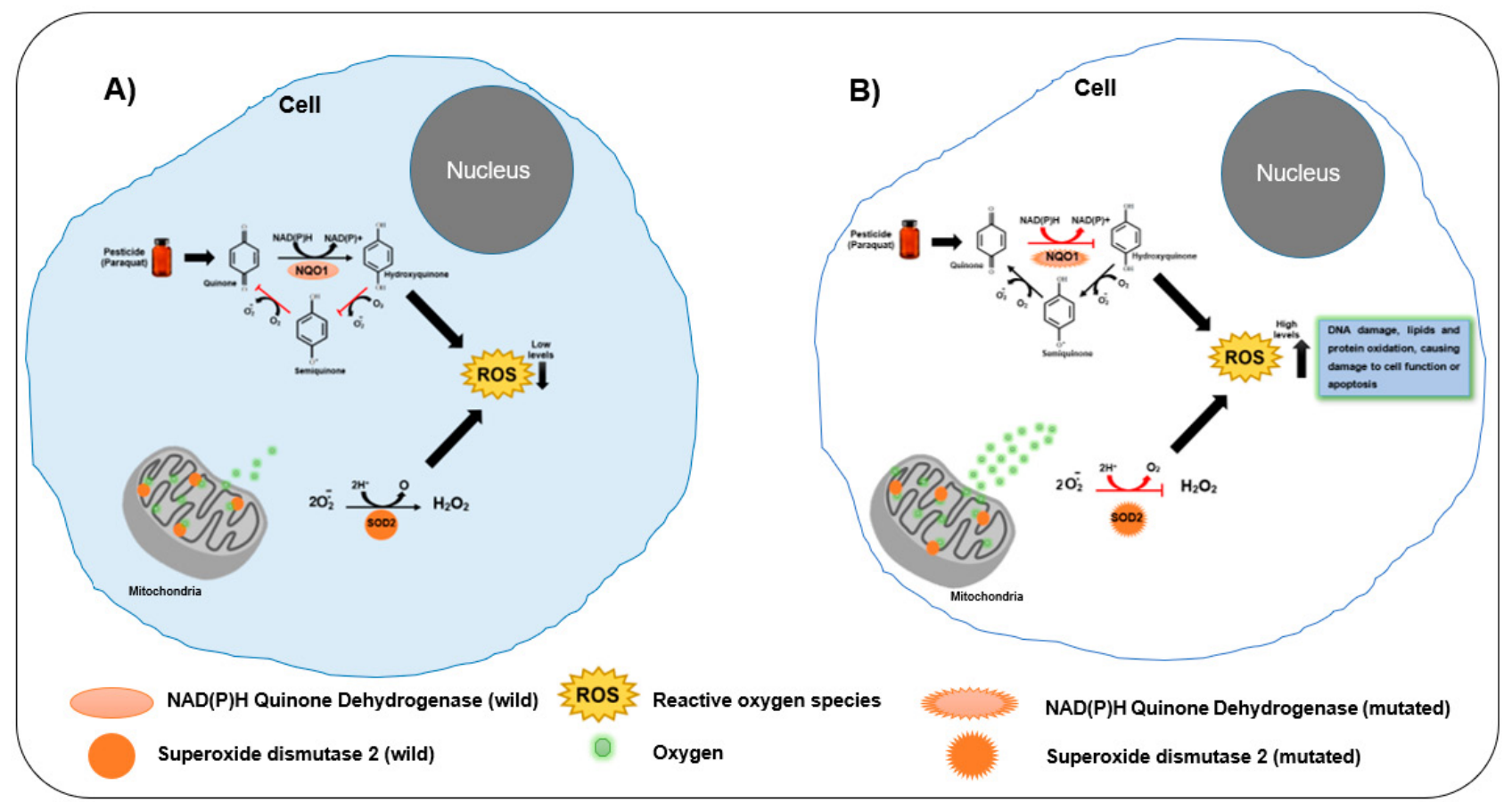

Figure 3. Actuating genes against oxidative stress. A - normal functioning of wild variants of NQO1 and SOD2; B - Abnormal functioning of mutated variants of NQO1 and SOD2.

cytosine to thymine, with the variant mutant allele $(-108 \mathrm{~T})$ showing a reduced enzyme activity due to lower expression of the PON1 gene [43]. In the polymorphism of the coding region $r s 854560$, there is an amino acid substitution in position 55 from leucine (ATG) to methionine (TTG). In the rs854560 coding region polymorphism there is an amino acid substitution at position 55 from leucine (ATG) to methionine (TTG). The resulting 55M mutated variant expresses a lower concentration of the enzyme in the bloodstream, which also results in reduced enzyme activity. This variant is associated with the mutated allele of the $108 \mathrm{~T}$ polymorphism in the promoter region $[41,35,43,44]$. In the rs 662 polymorphism of the coding region, there is an amino acid change at position 192 from glutamine (CAA) to arginine (CGA), which results in a structural change in the enzyme that affects its activity, depending on the metabolized substrate (Fig. 2). For example, the $192 \mathrm{R}$ mutated variant has a low efficiency in metabolizing the pesticide chlorpyrifos $[31,41,43,44]$.

Genes against oxidative stress. The damage produced by pesticides is mainly due to the formation of free radicals during their bio-transformation. These free radicals, which are predisposing factors for carcinogenesis, produce oxidative stress through oxidative DNA damage $[2,45]$. However, some enzymes with antioxidant activity can neutralize these free radicals, although antioxidant enzymes may have variants or polymorphisms that alter their activities $[4,46]$. The superoxide dismutase (SOD2) gene neutralizes superoxide anion produced in the mitochondrial respiratory chain $[47$, 48]. The enzyme NAD(P)H quinone oxidoreductase 1 (NQO1) gene is responsible for reducing free radicals from pesticide that produce residues with quinone structures [3, 49].

SOD2. The SOD2 gene is located on chromosome 6q25, with 5 exons and 4 introns $[50,51]$. It encodes the enzyme manganese superoxide dismutase ( $M n S O D$ or SOD2), a homotetramer with a manganese ion $\left(\mathrm{Mn}^{2+} / \mathrm{Mn}^{3+}\right)$ as a cofactor in each subunit $[29,48]$. SOD2 is an antioxidant enzyme in the mitochondrial matrix that catalyzes the dismutation of the mitochondrial superoxide anion into hydrogen peroxide and oxygen; in addition, it is involved in the regulation of apoptosis in tumors $[47,51,52]$. SOD2 is highly polymorphic, where the SNP rs4880 (exon 2, Ala16Val; $47 \mathrm{C}>\mathrm{T})$ is of medical importance $[45,50,52,53]$. The amino acid change in this polymorphism results in structural transformation of the protein: the protein with the alanine allele (GTT) produces an $\alpha$-helical structure, while the valine allele (GCT) results in a $\beta$-laminar secondary structure. The mutated allele (Val) has a decreased ability to neutralize the superoxide anion, because the promoted change in its structure prevents it from easily crossing the mitochondrial membrane, unlike the wild-type allele (Ala) which crosses it quickly (Fig. 3) [46, 50, 52].

NQO1. $\mathrm{NAD}(\mathrm{P}) \mathrm{H}$ quinone oxidoreductase 1 is a cytosolic enzyme encoded by the NQO1 gene located on the long arm of chromosome $16(16 q 22.1)[49,54,55]$. It catalyzes the reduction of quinone compounds to form hydroquinone, with $\mathrm{NAD}(\mathrm{P}) \mathrm{H}$ as coenzyme, thus reducing the concentration of free quinone which produces cytotoxicity $[3,49,55,56]$. However, SNPs can generate different isoforms with reduced enzymatic activity of $\mathrm{NAD}(\mathrm{P}) \mathrm{H}$ quinone oxidoreductase 1 , thus increasing the possibility of oxidative stress and cellular damage (Fig. 3). The rs1800566 polymorphism of NQO1 gene is associated with a reduction in the activity of the enzyme $\mathrm{NAD}(\mathrm{P}) \mathrm{H}$ quinone oxidoreductase 1 , in which there is a base change from cytosine to thymine at position 187, resulting in the substitution of proline for serine $[3,45,49,55,57]$. A reduced enzyme potential has also been observed in the mutated homozygous genotype (TT) and in the heterozygous genotype (CT), relative to the homozygous wild-type (CC) genotype $[3,54,57]$. 


\section{CONCLUSIONS}

The presented review shows the possible application of a genetic profile with 10 gene polymorphisms involved in susceptibility to pathologies due to exposure to pesticides. Thus, if the genetic profile of each exposed farmer is known, it will be possible to avoid both short-term and long-term pathologies. This genetic profile has given rise to a new branch of genetics that the authors of this review would like to call Agricultugenetics. In the future, Agricultugenetics will be used to analyze all 10 gene polymorphisms to determine the degree of risk of susceptibility to pesticide-associated pathologies in exposed farmers. This could reduce mortality from poisonings and diseases related to oxidative stress, especially cancer.

\section{REFERENCES}

1. Arévalo-Jaramillo P, Idrobo A, Salcedo L, Cabrera A, Vintimilla A, Carrión M, Bailon-Moscoso N. Biochemical and genotoxic effects in women exposed to pesticides in Southern Ecuador. Environ Sci Pollut Res. 2019; 26(24): 24911-24921.

2. Markus V, Teralı K, Dalmizrak O, Ozer N. Assessment of the inhibitory activity of the pyrethroid pesticide deltamethrin against human placental glutathione transferase P1-1: A combined kinetic and docking study. Environ Toxicol Pharmacol. 2018; 61: 18-23. https:// doi.org/10.1016/j.etap.2018.05.013

3. Ahmadi N, Mandegary A, Jamshidzadeh A, Mohammadi-Sardoo M, Mohammadi-Sardo M, Salari E, Pourgholi L. Hematological abnormality, oxidative stress, and genotoxicity induction in the greenhouse pesticide sprayers; investigating the role of NQO1 gene polymorphism. Toxics. 2018; 6(1): 1-15. 10.3390/toxics6010013

4. Garcia-Rodriguez A, de la Casa M, Serrano M, Gosálvez J, Roy Barcelona R. Impact of polymorphism in DNA repair genes OGG1 and XRCC1 on seminal parameters and human male infertility. Andrologia. 2018; 50(10): 1-7. https://doi.org/10.1111/and.13115

5. Zhang, Jiang D, Wang C, Garzotto M, Kopp R, et al. Polymorphisms in oxidative stress pathway genes and prostate cancer risk. Cancer Causes and Control. 2019; 30(12): 1365-1375.

6. Sharma N, Singhvi R. Effects of Chemical Fertilizers and Pesticides on Human Health and Environment: A Review. International Journal of Agriculture, Environment and Biotechnology. 2017; 10(6): 675-679. doi: 10.5958/2230-732X.2017.00083.3

7. Zhang C, Hu R, Huang J, Huang X, Shi G, et al. Health effect of agricultural pesticide use in China: implications for the development of GM crops. Scientific Reports. 2016; 6(34918): 1-8. https://doi. org/10.1038/srep34918

8. de Adad LMM, De Andrade HHR, Kvitko K, Lehmann M, de Cavalcante AACM, Dihl RR. Occupational exposure of workers to pesticides: Toxicogenetics and susceptibility gene polymorphisms. Genet Mol Biol. 2015; 38(3): 308-315. http://dx.doi.org/10.1590/S1415475738320140336

9. Godoy FR, Nunes HF, Alves AA, Carvalho WF, Franco FC, et al. Increased DNA damage is not associated to polymorphisms in OGGI DNA repair gene, CYP2E1 detoxification gene, and biochemical and hematological findings in soybeans farmers from Central Brazil. Environ Sci Poll Res. 2019; 26(26): 26553-26562.

10. Silva VF, Simon D, de Souza MR, da Rosa VH, Nicolau C, et al. Base excision repair (OGG1 and XRCC1) and metabolism (PON1) gene polymorphisms act on modulation of DNA damage and immune parameters in tobacco farmers. Mutat Res Genet Toxicol Environ Mutagen. 2018; 836 9-18. https://doi.org/10.1016/j.mrgentox.2018.04.001

11. de Oliveira AFB, de Souza MR, Benedetti D, Scotti AS, Piazza LS, et al. Investigation of pesticide exposure by genotoxicological, biochemical, genetic polymorphic and in silico analysis. Ecotoxicol Environ Saf. 2019; 179: 135-142. https://doi.org/10.1016/j.ecoenv.2019.04.023

12. Mahmoud AA, Hassan MH, Ghweil AA, Abdelrahman A, Mohammad AN, Ameen $\mathrm{HH}$. Urinary 8-hydroxydeoxyguanosine in relation to XRCC1 rs25487 G/A (Arg399Gln) and OGG1 rs1052133 C/G (Ser326Cys) DNA repair genes polymorphisms in patients with chronic hepatitis C and related hepatocellular carcinoma. Cancer Manag Res. 2019; 11: 5343-5351. https://dx.doi.org/10.2147\%2FCMAR.S209112
13. Saad-Hussein A, Noshy M, Taha M, El-Shorbagy H, Shahy E, AbdelShafy EA. GSTP1 and XRCC1 polymorphisms and DNA damage in agricultural workers exposed to pesticides. Mutat Res Genet Toxicol Environ Mutagen. 2017; 819: 20-25. https://doi.org/10.1016/j. mrgentox.2017.05.005

14. Kaur J, Sambyal V, Guleria K, Singh NR, Uppal MS, Manjari M, Sudan M. Association of XRCC1, XRCC2 and XRCC3 Gene Polymorphism with Esophageal Cancer Risk. Clin Exp Gastroenterol. 2020; 13: 73-86. https://dx.doi.org/10.2147\%2FCEG.S232961

15. de Melo e Silva D, Alves AA, Nunes HF, Ramos JSA, Franco FC, Soares TN. Evaluating the OGG1 rs1052133 and rs293795 polymorphisms in a sample of rural workers from Central Brazil population: a comparative approach with the 1000 Genomes Project. Environ Sci Pollut Res. 2018; 25(25) 25612-25617. https://doi.org/10.1007/s11356-018-2766-8

16. Garcia JA, Kalacas NA, Ortin TS, Ramos MC, Albano PM. XRCC4 c.1394G > T single nucleotide polymorphisms and breast cancer risk among filipinos. Asian Pac J Cancer Prev. 2019; 20(4): 1097-1101. https:// dx.doi.org/10.31557\%2FAPJCP.2019.20.4.1097

17. Gupta MK, Kushwah AS, Singh R, Banerjee M. Genotypic analysis of XRCC4 and susceptibility to cervical cancer. Br J Biomed Sci. 2020; 77(1): 7-12 https://doi.org/10.1080/09674845.2019.1637573

18. Singh PK, Mistry KN, Chiramana H, Rank DN, Joshi CG. Exploring the deleterious SNPs in XRCC4 gene using computational approach and studying their association with breast cancer in the population of West India. Gene. 2018; 655: 13-19. https://doi.org/10.1016/j. gene.2018.02.040

19. Floris M, Sanna D, Castiglia P, Putzu C, Sanna V, et al. MTHFR, XRCC1 and OGG1 genetic polymorphisms in breast cancer: a case-control study in a population from North Sardinia. BMC Cancer. 2020; 20(234): 1-15. https://doi.org/10.1186/s12885-020-06749-w

20. Fujihara J, Yasuda T, Iwata H, Tanabe S, Takeshita H. Association of XRCC1 polymorphisms with arsenic methylation. Arch Toxikol. 2016; 90(4): 1009-1012. doi: 10.1007/s00204-015-1490-0

21. Sobiahe A, Hijazi E, Al-Ameer HJ, Almasri Y, Jarrar Y, et al. Arg399Gln XRCC1 Polymorphism and Risk of Squamous Cell Carcinoma of the Head and Neck in Jordanian Patients. Asian Pac J Cancer Prev. 2020; 21(3): 663-665. https://dx.doi.org/10.31557/APJCP.2020.21.3.663

22. Xu C, Xu J, Ji G, Liu Q, Shao W, et al. Deficiency of X-ray repair crosscomplementing group 1 in primordial germ cells contributes to male infertility. FASEB J. 2019; 33(6): 7427-7436. https://doi.org/10.1096/ fj.201801962RR

23. Hassan FM. OGG1 rs1052133 polymorphism and genetic susceptibility to chronic myelogenous leukaemia. Asian Pac J Cancer Prev. 2019; 20(3): 925-928. https://dx.doi.org/10.31557\%2FAPJCP.2019.20.3.925

24. Dinçer Y, Akkaya Ç, Mutlu T, Yavuzer S, Erkol G, Bozluolcay M, Guven M. DNA repair gene OGG1 polymorphism and its relation with oxidative DNA damage in patients with Alzheimer's disease. Neurosci Lett. 2019; 709: 134362. https://doi.org/10.1016/j.neulet.2019.134362

25. Das S, Nath S, Bhowmik A, Ghosh SK, Choudhury Y. Association between OGG1 Ser326Cys polymorphism and risk of upper aerodigestive tract and gastrointestinal cancers: a meta-analysis. SpringerPlus. 2016; 5: 1-11. https://doi.org/10.1186/s40064-016-1858-5

26. Sanjari MA, Nazarzadeh M, Noroozi R, Darvish H, Jarrahi AM. XRCC1 and OGG1 gene polymorphisms and breast cancer: A systematic review of literature. Int J Cancer Man. 2016; 9(1): e3467. https://dx.doi. org/10.17795\%2Fijcp-3467

27. Pehlivan S, Balci SO, Aydeniz A, Pehlivan M, Sever T, Gursoy S. Might there be a link between intron 3 VNTR polymorphism in the XRCC4 DNA. Genet Test Mol Biomarkers. 2015; 19(1): 48-51. https://doi. org/10.1089/gtmb.2014.0230

28. Saito S, Kurosawa A, Adachi N. Mutations in XRCC4 cause primordial dwarfism without causing immunodeficiency. J Hum Genet. 2016; 61: 679-685.https://doi.org/10.1038/jhg.2016.46

29. Silva VF, da Silva FR, Alves JS, da Silva GF, Picinini J, et al. Role of PON1, SOD2, OGG1, XRCC1, and XRCC4 polymorphisms on modulation of DNA damage in workers occupationally exposed to pesticides. Ecotoxicol Environ. 2018; 15(159): 164-171. https://doi.org/10.1016/j. ecoenv.2018.04.052

30. Wen Y, Dai G, Wang L, Fu K, Zuo S. Silencing of XRCC4 increases radiosensitivity of triple-negative breast cancer cells. Biosci Rep. 2019; 39(3): 1-30. https://doi.org/10.1042/BSR20180893

31. Alleva R, Manzella N, Gaetani S, Bacchetti T, Bracci M, et al. Mechanism underlying the effect of long-term exposure to low dose of pesticides on DNA integrity. Environ Toxicol. 2018; 33(4): 476-487. https://doi. org/10.1002/tox.22534

32. Kudhair BK, Alabid NN, Taheri-Kafrani A, Lafta IJ. Correlation of GSTP1 gene variants of male Iraqi waterpipe (Hookah) tobacco smokers 
and the risk of lung cancer. Mol Biol Rep. 2020; 47: 2677-2684. https:// doi.org/10.1007/s11033-020-05359-w

33. Mandal RK, Mittal RD. Glutathione S-Transferase P1 313 (A > G) Ile105Val Polymorphism Contributes to Cancer Susceptibility in Indian Population: A Meta-analysis of 39 Case-Control Studies. Indian J Clin Biochem. 2020; 35(1): 8-19. https://doi.org/10.1007/s12291-018-0787-1

34. Dardiotis E, Aloizou AM, Siokas V, Tsouris Z, Rikos D, et al. Paraoxonase-1 genetic polymorphisms in organophosphate metabolism. Toxicol. 2019; 411: 24-31. https://doi.org/10.1016/j.tox.2018.10.012

35. Xotlanihua-Gervacio MC, Herrera-Moreno JF, Medina-Díaz IM, Bernal-Hernández YY, Rothenberg SJ, Barrón-Vivanco BS, RojasGarcía AE. Relationship between internal and external factors and the activity of PON1. Environ Sci Poll Res. 2019; 26(24): 24946-24957. https://doi.org/10.1007/s11356-019-05696-9

36. Luo Y, Tan Y, Wang X. Influence of polymorphisms in VEGF, TNF- $\alpha$, and GSTP1 genes on retinopathy of prematurity risk: a Meta-analysis J of Matern Fetal Neonatal Med. 2020; 86: 1-10. https://doi.org/10.10 80/14767058.2020.1745179

37. Drozdz-Afelt JM, Koim-Puchowska B, Klosowski G and Kaminski P. Polymorphism of glutathione S-transferase in the population of Polish patients with carcinoma of the prostate. Environ Sci Poll Res. 2020; 27: 19375-19382. https://doi.org/10.1007/s11356-020-08435-7

38. Idris HM, Elderdery AY, Khalil HB, Mills J. Genetic Polymorphism of GSTP1, GSTM1 and GSTT1 Genes and Susceptibility to Chronic Myeloid Leukaemia. Asian Pac J Cancer Prev. 2020; 21(2): 499-503. https://dx.doi.org/10.31557/APJCP.2020.21.2.499

39. Tian M, Zhao B, Martin FL, Morais CLM, Liu L, et al. Gene-environment interactions between GSTs polymorphisms and targeted epigenetic alterations in hepatocellular carcinoma following organochlorine pesticides (OCPs) exposure. Environ Int. 2020; 134: 105313. https:// doi.org/10.1016/j.envint.2019.105313

40. Lee YH, Kim JH, Seo YH, Choi SJ, Ji JD, Song GG. Paraoxonase 1 Q192R and L55M polymorphisms and susceptibility to amyotrophic lateral sclerosis: a meta-analysis. Neurol Sci. 2015; 36(1): 11-20. https://doi. org/10.1007/s10072-014-1979-y

41. Mota A, Hemati-Dinarvand M, Akbar TA, Reza NH, Ahmadi R, et al. Association of Paraoxonsel (PON1) Genotypes with the Activity of PON1 in Patients with Parkinson's Disease. Acta Neurol Taiwan. 2019; 28(3): 66-74

42. Medina-Díaz IM, Ponce-Ruiz N, Ramírez-Chávez B, Rojas-García AE, Barrón-Vivanco BS, Elizondo G, Bernal-Hernández YY. Downregulation of human paraoxonase 1 (PON1) by organophosphate pesticides in HepG2 cells. Environ Toxicol. 2017; 32(2): 490-500. https:// doi.org/10.1002/tox.22253

43. Torres-Sánchez L, Gamboa R, Bassol-Mayagoitia S, Huesca-Gómez C, Nava MP, et al. Para-occupational exposure to pesticides, PON1 polymorphisms and hypothyroxinemia during the first half of pregnancy in women living in a Mexican floricultural area. Environ Health. 2019; 18(33): 1-10. https://doi.org/10.1186/s12940-019-0470-x

44. Sunay SZ, Kayaaltı Z, Bayrak T, Söylemezoğlu T. Effect of paraoxonase $1192 \mathrm{Q} / \mathrm{R}$ polymorphism on paraoxonase and acetylcholinesterase enzyme activities in a Turkish population exposed to organophosphate. Toxicol Ind Health. 2015; 31(12): 1061-1068. https://doi. org/10.1177\%2F0748233713487246
45. Amr S, Dawson R, Saleh DA, Magder LS, George DM, et al. Pesticides, Gene Polymorphisms, and Bladder Cancer among Egyptian Agricultural Workers. Arch Environ Occup Health. 2015; 70(1): 19-26. https://doi.org/10.1080/19338244.2013.853646

46. Pourvali K, Abbasi M, Mottaghi A. Role of superoxide dismutase 2 gene Ala16Val polymorphism and total antioxidant capacity in diabetes and its complications. Avicenna J Med Biotechnol. 2016; 8: 48-56.

47. Ait TAEK, Becquemont L, El-Asmar K, Mahmoudi K, Colle R, et al. SOD2 genetic polymorphism (rs4880) has no impact on 6-month response to antidepressant treatment and inflammatory biomarkers in depressed patients. Basic Clin Pharmacol Toxicol. 2020; 126(3): 289-295. https://doi.org/10.1111/bcpt.13385

48. Kim YS, Vallur PG, Phaëton R, Mythreye K, Hempel N. Insights into the dichotomous regulation of SOD2 in cancer. Antioxidants. 2017; 6(86): 1-25. https://doi.org/10.3390/antiox6040086

49. Moumad K, Khaali W, Benider A, Ben AW, Hamdi-Cherif M, et al. Joint effect of smoking and NQO1 C609T polymorphism on undifferentiated nasopharyngeal carcinoma risk in a North African population. Mol Genet Genomic Med. 2018; 6(6): 933-940. https://doi.org/10.1002/ mgg3.461

50. Dragicevic B, Suvakov S, Jerotic D, Reljic Z, Djukanovic L, et al. Association of SOD2 (Rs4880) and GPX1 (rs1050450) gene polymorphisms with risk of Balkan endemic nephropathy and its related tumors. Medicina (Lithuania). 2019; 55(8): 1-10. https://doi. org/10.3390/medicina55080435

51. Taş A, Siliğ Y, Pinarbaşi H, Gürelik M. Role of SOD2 ala16Val polymorphism in primary brain tumors. Biomed Rep. 2019; 10(3): 189-194. https://doi.org/10.3892/br.2019.1192

52. Berto MD, Bica CG, de Sá GP, Barbisan F, Azzolin VF, et al. The effect of superoxide anion and hydrogen peroxide imbalance on prostate cancer: an integrative in vivo and in vitro analysis. Medical Oncol. 2015; 32(11): 251. https://doi.org/10.1007/s12032-015-0700-1

53. Liu C, Fang J, Liu W. Superoxide dismutase coding of gene polymorphisms associated with susceptibility to Parkinson's disease. J Integ Neurosci. 2019; 18(3): 299-303. http://doi.org/10.31083/j. jin. 2019.03.127\%20

54. Silva CB, Mota CL, Almeida YR, Emídio V, Fonseca ASA, Mitri S, Moreira JC. Environmental exposure to benzene: evaluation of urinary S-PMA and polymorphism (CYP2E1-1293G $>$ C and NQO1 $609 \mathrm{C}>\mathrm{T}$ ) in Campos Elíseos residents, Duque de Caxias, Rio de Janeiro State, Brazil. Cad Saude Publica. 2019; 35(7): e00198618. https://doi. org/10.1590/0102-311X00198618

55. Zhao L, Liu J, Tan P, Zhang W, Gao Q, et al. Genetic association of the NQO1 rs1800566 $(609 \mathrm{C}>\mathrm{T})$ variant with risk of preeclampsia in the Chinese Han population. Pregnancy Hypertens. 2017; 10: 42-45. https://doi.org/10.1016/j.preghy.2017.05.004

56. Yu L, Hu Y, Ding Y. Association of maternal xenobiotic-metabolizing gene polymorphisms with risk of fetal growth restriction. Per Med. 2019; 16(4): 269-276. https://doi.org/10.2217/pme-2018-0125

57. Chung JE, Chang BC, Lee KE, Kim JH, Gwak HS. Effects of NAD(P)H quinone oxidoreductase 1 polymorphisms on stable warfarin doses in Korean patients with mechanical cardiac valves. Eur J Clin Pharmacol. 2015; 71(10): 1229-1236. https://doi.org/10.1007/s00228-015-1915-y 